\title{
Grupo Colaborativo de Resistencia Bacteriana. Mucho más que 10 años de historia
}

\author{
Jaime Labarca
}

\author{
Bacterial Resistance Collaborative Group. Much more than 10 years history
}

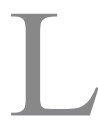
a resistencia bacteriana se ha consolidado como un importante problema de salud pública, debido a que, a pesar de todos los esfuerzos, continúa aumentando, situación agravada por la ausencia de nuevos antimicrobianos ${ }^{1}$. Nuestro país ha hecho esfuerzos por controlar la resistencia antimicrobiana y un buen ejemplo de ello es la ley de receta obligatoria para la dispensación de antimicrobianos en la comunidad ${ }^{2}$. Estamos cumpliendo diez años de la primera reunión de trabajo en Resistencia Bacteriana en Chile, que nació en el año 2004 como respuesta a las inquietudes de los médicos sobre los problemas de resistencia que viven en sus hospitales, y la necesidad de crear instancias de interacción y de generar información local del país. Hasta esa fecha la información producida en el país era relativamente escasa, a pesar del reconocido nivel de la infectología y de la microbiología chilena.

En sus albores fue una iniciativa de la industria farmacéutica. Sin embargo, después de varios años se transformó en un grupo de trabajo colaborativo perteneciente a la Sociedad Chilena de Infectología. Además de profundizar en el conocimiento de la resistencia bacteriana, esta reunión contempla instancias formales que permiten y fomentan el intercambio de opiniones entre los asistentes, en una discusión enriquecedora. En esta reunión no se viene sólo a escuchar; los asistentes pueden compartir experiencias, discutir temas comunes, y llegar a acuerdos que incluso se podrían implementar como políticas en sus propios hospitales y eventualmente a nivel nacional.

Este grupo ha alcanzado logros significativos, como recopilar la información de la resistencia local de antimicrobianos de más de 30 hospitales del país. En el año 2011 se publicaron los primeros datos de resistencia bacteriana de un número acotado de hospitales ${ }^{3}$. En este número de la revista se publica un segundo reporte con los datos de resistencia bacteriana del año 2012, correspondientes a 28 hospitales. También, en este periodo hemos logrado recolectar información preliminar de otros importantes indicadores, como es la incidencia de microorganismos resistentes en unidades de cuidados intensivos y la densidad del consumo de antimicrobianos, usando metodología recomendada ${ }^{4}$. Además, hemos avanzado en fijar criterios comunes para la prevención de la diseminación de bacterias resistentes a nivel hospitalario. Muy importantemente, hemos establecido una red de colaboración para la detección de nuevos mecanismos de resistencia bacteriana emergentes en nuestro país, teniendo como centros de referencia de nuestro grupo el Laboratorio de Antibióticos de la Universidad de Concepción y el Laboratorio de Microbiología de la P. Universidad Católica de Chile.

A pesar de los logros antes mencionados quedan todavía importantes desafíos para este grupo. Uno de ellos es convertir en rutina la vigilancia de incidencia de bacterias resistentes en unidades de pacientes críticos y la vigilancia del consumo de antimicrobianos en los hospitales. También, es muy importante fijar pautas comunes de estrategias para la prevención y control de la transmisión de bacterias en los hospitales, así como para el control del uso de antimicrobianos. Desde sus inicios, este grupo ha tenido el propósito de incluir la activa participación y el reconocimiento de otras sociedades científicas y las autoridades sanitarias involucradas en este importante problema de salud pública, tanto a nivel nacional como internacional ${ }^{5}$. En este sentido hemos ya dado los pasos

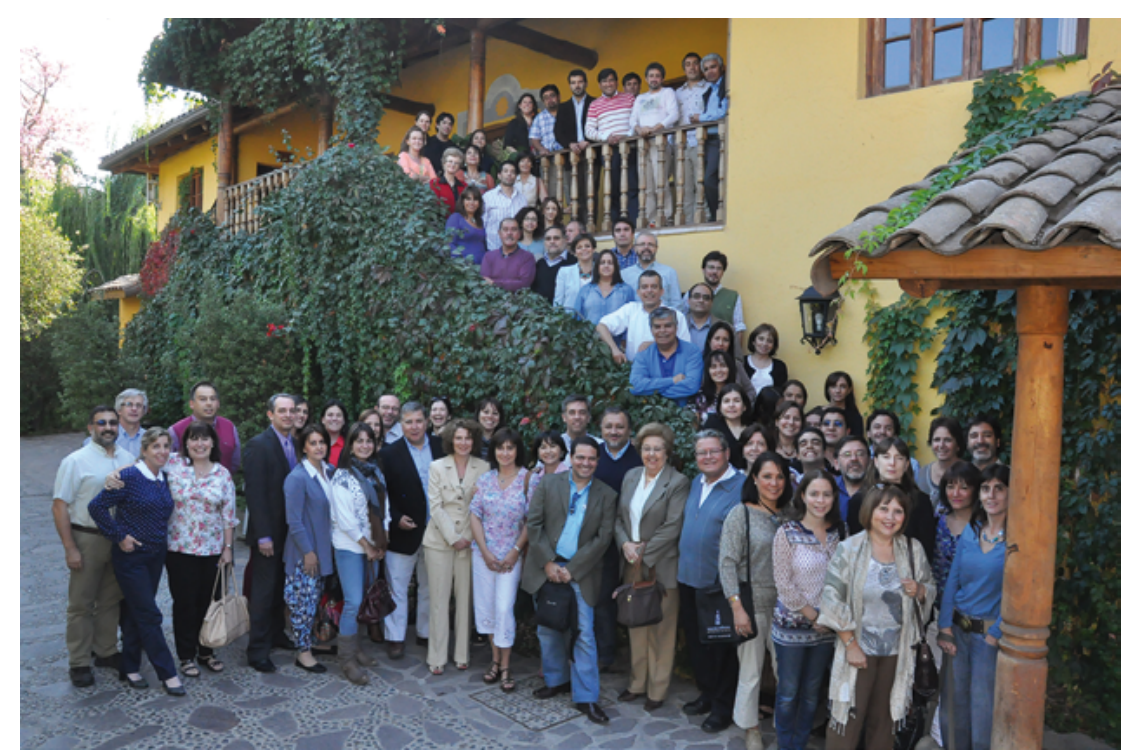


iniciales al participar en la creación del "Grupo de Trabajo en Infecciones en Pacientes Críticos" iniciativa conjunta de la Sociedad Chilena de Medicina Intensiva y Sociedad Chilena de Infectología. Nos alegramos por la creación reciente por el Ministerio de Salud de la "Comisión Nacional de Resistencia Microbiológica", en la cual participarán múltiples actores involucrados y entre ellos nuestra Sociedad Chilena de Infectología.

Esta instancia, a través de su reunión anual, ha permiti- do compartir momentos de interés científico y de amistad, generando así un vínculo de pertenencia. Así, el Grupo Colaborativo de Resistencia Bacteriana ha facilitado la integración entre todos nosotros con una mirada de país, por el bien de la medicina nacional y de nuestros pacientes. Consideramos sin duda que este capital humano, unidos en este grupo por el trabajo y la búsqueda del bien común, es el logro más importante que hemos tenido a los diez años de su inicio.

\section{Referencias bibliográficas}

1.- Arias C, Murray B. Antibiotic-Resistant Bugs in the 21 st Century-A clinical super-challenge. N Engl J Med 2009; 360: 439-43.

2.- Bavestrello L, Cabello A, Casanova D. Impact of regulatory measures in the trends of community consumption of antibiotics in Chile.
Rev Med Chile 2002; 130 (11): 1265-72.

3.- Silva F, Cifuentes M, Pinto M E. Resultados de la vigilancia de susceptibilidad antimicrobiana en Chile: Consolidando una red. Rev Chilena Infectol 2011; 28 (1): 19-27.

4.- Cohen A L, Calfee D, Fridkin S K, Huang S S, Jernigan J A, Lautenbach E, et al; Society for Healthcare Epidemiology of America and the
Healthcare Infection Control Practices Advisory Committee. Recommendations for metrics for multidrug-resistant organisms in healthcare settings: SHEA/HICPAC Position paper. Infect Control Hosp Epidemiol 2008; 29 (10): 901-13.

5.- Labarca J. Desde el aporte local al control de la resistencia bacteriana en Chile. Rev Chilena Infectol 2011; 28 (1): 12- 3. 